\title{
The frequency of genes encoding three putative group B streptococcal virulence factors among invasive and colonizing isolates
}

\author{
Shannon D Manning ${ }^{1}$, Moran $\mathrm{Ki}^{2}$, Carl F Marrs ${ }^{3}$, Kiersten J Kugeler ${ }^{4}$, \\ Stephanie M Borchardt ${ }^{5}$, Carol J Baker ${ }^{6}$ and Betsy Foxman*3
}

Address: ${ }^{1}$ National Food Safety and Toxicology Center and Department of Pediatrics and Human Development, Michigan State University, East Lansing, Michigan, USA, ${ }^{2}$ Department of Preventive Medicine, Eulji University School of Medicine, Daejeon, Korea, ${ }^{3}$ Department of Epidemiology, University of Michigan School of Public Health, Ann Arbor, Michigan, USA, ${ }^{4}$ Centers for Disease Control and Prevention, Division of Vector-Borne Infectious Diseases, Bacterial Zoonoses Branch, Fort Collins, Colorado, USA, ${ }^{5}$ Fargo Veterans Administration Medical Center, Fargo, North Dakota, USA and ${ }^{6}$ Department of Pediatrics, Molecular Virology and Microbiology, Baylor College of Medicine, Houston, Texas, USA

Email: Shannon D Manning - Shannon.Manning@ht.msu.edu; Moran Ki - kimoran@eulji.ac.kr; Carl F Marrs - cfmarrs@umich.edu; Kiersten J Kugeler - bio1@cdc.gov; Stephanie M Borchardt - Stephanie.Borchardt@va.gov; Carol J Baker - cbaker@bcm.tmc.edu; Betsy Foxman* - bfoxman@umich.edu

* Corresponding author

Published: 17 July 2006

BMC Infectious Diseases 2006, 6:116 doi:10.1186/147I-2334-6-116

This article is available from: http://www.biomedcentral.com/147I-2334/6/116

(c) 2006 Manning et al; licensee BioMed Central Ltd.

This is an Open Access article distributed under the terms of the Creative Commons Attribution License (http://creativecommons.org/licenses/by/2.0), which permits unrestricted use, distribution, and reproduction in any medium, provided the original work is properly cited.
Received: 07 March 2006

Accepted: 17 July 2006

\begin{abstract}
Background: Group B Streptococcus (GBS) causes severe infections in very young infants and invasive disease in pregnant women and adults with underlying medical conditions. GBS pathogenicity varies between and within serotypes, with considerable variation in genetic content between strains. Three proteins, Rib encoded by rib, and alpha and beta $C$ proteins encoded by bca and bac, respectively, have been suggested as potential vaccine candidates for GBS. It is not known, however, whether these genes occur more frequently in invasive versus colonizing GBS strains.
\end{abstract}

Methods: We screened 162 invasive and 338 colonizing GBS strains from different collections using dot blot hybridization to assess the frequency of bca, bac and rib. All strains were defined by serotyping for capsular type, and frequency differences were tested using the Chi square test.

Results: Genes encoding the beta $C$ protein (bac) and Rib (rib) occurred at similar frequencies among invasive and colonizing isolates, bac ( $20 \%$ vs. $23 \%)$, and rib ( $28 \%$ vs. $20 \%)$, while the alpha (bca) C protein was more frequently found in colonizing strains (46\%) vs, invasive (29\%). Invasive strains were associated with specific serotype/gene combinations.

Conclusion: Novel virulence factors must be identified to better understand GBS disease.

\section{Background}

Group B Streptococcus (GBS) causes sepsis and meningitis in young infants, febrile complications in pregnant women and invasive disease in adults with underlying medical conditions [1]. Capsular polysaccharide, which defines GBS serotype, is the primary virulence factor found in most GBS strains, and different serotypes contribute to disease in different populations. For example, $30 \%$ of GBS disease in non-pregnant adults is caused by serotype $\mathrm{V}$ [2], while serotype III causes more than $70 \%$ of 
infant meningitis and most late-onset (7-89 days of age) disease [3]. Vaccines currently under development target the most prevalent GBS serotypes [4].

Other than the polysaccharide capsule, little is known about other GBS components important in pathogenesis. Many putative virulence factors and genes have been identified recently (for a review see [5]), though most are either present in all GBS strains, or are lacking sufficient data to pinpoint their role in the pathogenic process. Three proteins, however, have been studied extensively and were recommended as potential GBS vaccine candidates [6-8]. These include the protein Rib [7] encoded by rib [9], and the alpha [10] and beta [10] C proteins encoded by $b c a$ [11] and bac [12], respectively. All three proteins trigger antibody production that offers protection from GBS infection in animal models [7,8,13], though the frequency of these proteins and the genes that encode them varies by disease status [14-19] as well as serotype. For example, Rib has been found predominantly in serotype III strains [7]. To date, large, population-based studies comparing the frequencies of genes encoding the $\mathrm{Rib}$, alpha and beta $\mathrm{C}$ proteins among invasive and colonizing isolates have been limited.

\section{Methods}

We describe the frequency of genes encoding three virulence factors among five GBS strain collections including invasive $(\mathrm{n}=162)$ and colonizing $(\mathrm{n}=338)$ isolates (Table 1); invasive disease status was not known for 29 strains. All isolates tested were obtained with the approval of an appropriate institutional ethics committee. Invasive isolates originated from the blood or cerebrospinal fluid (CSF) of newborns $<7$ days of age $(n=100)$, the urine of college students $(n=4)[20,21]$ and pregnant women presenting to the University of Michigan Medical Center (UMMC) for prenatal care associated with GBS isolation from the urine $(\mathrm{n}=58)$, and the placenta following delivery $(n=5)$ [22]. Newborn isolates, described by Zaleznik et al. [23] $(\mathrm{n}=65)$, were collected between 1993 and 1996 , while the remainder $(\mathrm{n}=35)$ came from the same Houston hospitals between 1997 and 2000. Colonizing GBS isolates were from the anal orifice or urine of healthy male $(n=58)$ college students, the anal orifice, vagina, cervix or urine or healthy female $(n=86)$ college students [21], pregnant women from UMMC $(n=49)$ [22], and sexually active college women with a urinary tract infection not caused by GBS $(\mathrm{n}=102)$ and their most recent male sex partner $(\mathrm{n}=43)$ [20]. Among colonizing isolates, 17 (6.9\%) were from individuals colonized with multiple isolates in multiple sites; the dot blot profile was determined only for those isolates that were unique by pulsedfield gel electrophoresis (PFGE) as described previously $[20,21,24]$.
Serotyping using hyperimmune rabbit antisera to GBS polysaccharide types Ia, Ib, and II-VIII was performed as described previously $[20,21]$. We amplified DNA for genes encoding $b c a, b a c$ and $r i b$ using PCR (Table 2). Control strain A909 was used to amplify bca and bac [25], while BM110 was used for rib [9]. PCR DNA was purified and fluorescein-labeled as described previously [26].

DNA was isolated using a modified E. coli protocol [27] in which cells were lysed overnight. Dot blot hybridization and subsequent analyses were performed as described previously $[26,28]$ with two negative and positive controls per membrane. The signal intensity of each dot was reported as a percentage of the positive control present on each membrane in ImageQuant (Molecular Dynamics, CA). Percentages were corrected for the background signal of the negative controls and graphed. The $\mathrm{x}$-axis represented values from one membrane and the y-axis consisted of values from the duplicate membrane. A cutoff was established based on each graph distribution [26]. Isolates within the intermediate range were repeated. Sixty-eight hybridizations yielded equivocal results despite repeated probing, and thus, were confirmed for the presence or absence of each gene by PCR and sequencing using the same primers described in Table 2. Eleven remained equivocal following PCR and were excluded from the analyses.

Chi square tests were used to assess differences in gene frequencies by collection and serotype. SAS was used for all statistical analyses [29].

\section{Results}

Across GBS strain collections, the $b c a$ gene occurred most frequently, followed by rib and $b a c$ (Table 3). $b c a$ and $b a c$ occurred most frequently among colonizing isolates from college students (Collections 1, 2, and 4, Table 1), while the frequency of $r i b$ was similar across collections. Because gene frequency varies by capsular serotype, we described the frequency of each gene by serotype (Figure 1). When assessing the frequencies among invasive versus colonizing isolates, only isolates from newborns with GBS disease $(n=100)$ were considered invasive, while colonizing isolates consisted of those isolates known to not cause a UTI and those that were isolated during pregnancy as part of routine GBS screening $(\mathrm{n}=360)$. In this analysis, rib occurred slightly more frequently among invasive versus colonizing isolates $(\mathrm{p}=.09)$ (Table 4), while both bac (p $=.55)$ and $b c a(\mathrm{p}=.002)$ occurred less frequently in the invasive strains.

After stratifying by serotype, invasive versus colonizing capsular serotype Ia strains were significantly less likely to have bca $(\mathrm{p}=.002)$, while Ib invasive strains were more likely to have bca $(\mathrm{p}=.03)$ (Table 4$)$. Invasive versus col- 
Table I: Number of group B streptococcal isolates $(n=529)$ screened via dot blot hybridization and characteristics of each collection*.

\begin{tabular}{|c|c|c|c|c|c|}
\hline GBS Collection & Isolation source & Culture date & Age range & Race/ethnicity & Number of strains \\
\hline $\begin{array}{l}\text { Ia. Sexually active college } \\
\text { women with UTI receiving care } \\
\text { from a Student Health Services at } \\
\text { the University of Michigan (UM) } \\
\text { [22]. }\end{array}$ & $\begin{array}{l}\text { urine, anal orifice, } \\
\text { vaginal }\end{array}$ & $\begin{array}{l}\text { Sept. } 1996 \text { to April } \\
1999\end{array}$ & $18-30$ & $\begin{array}{l}\text { White (76\%), Non- } \\
\text { White (24\%) }\end{array}$ & $\begin{array}{l}\text { Colonizing }(n=102) \\
\text { Invasivet }(n=2)\end{array}$ \\
\hline $\begin{array}{l}\text { Ib. Most recent male sex } \\
\text { partner of women with UTI } \\
\text { receiving care from the Student } \\
\text { Health Services at UM [22]. }\end{array}$ & urine, anal orifice & $\begin{array}{c}\text { Sept. } 1996 \text { to April } \\
1999\end{array}$ & $18-35$ & $\begin{array}{l}\text { White (7I\%), Non- } \\
\text { White (29\%) }\end{array}$ & $\begin{array}{l}\text { Colonizing }(n=43) \\
\text { Invasive† }(n=0)\end{array}$ \\
\hline $\begin{array}{l}\text { 2a. Sexually active college } \\
\text { women without UTI presenting } \\
\text { to the Student Health Services at } \\
\text { UM [22]. }\end{array}$ & $\begin{array}{l}\text { urine, anal orifice, } \\
\text { vaginal }\end{array}$ & $\begin{array}{l}\text { Sept. } 1996 \text { to April } \\
1999\end{array}$ & $18-28$ & $\begin{array}{l}\text { White (80\%), Non- } \\
\text { White (20\%) }\end{array}$ & $\begin{array}{l}\text { Colonizing }(n=57) \\
\text { Invasivet }(n=0)\end{array}$ \\
\hline $\begin{array}{l}\text { 2b. Most recent male sex } \\
\text { partner of women without UTI } \\
\text { presenting to the Student Health } \\
\text { Services at UM [22]. }\end{array}$ & urine, anal orifice & $\begin{array}{c}\text { Sept. } 1996 \text { to April } \\
1999\end{array}$ & $19-33$ & $\begin{array}{l}\text { White }(73 \%), \text { Non- } \\
\text { White }(27 \%)\end{array}$ & $\begin{array}{l}\text { Colonizing }(n=35) \\
\text { Invasivet }(n=0)\end{array}$ \\
\hline $\begin{array}{l}\text { 3. Newborns with early onset } \\
\text { disease from hospitals affiliated } \\
\text { with Baylor College of Medicine } \\
\text { [19]. }\end{array}$ & blood, CSF & 1993 to 2000 & $<7$ days & $\begin{array}{l}\text { Hispanic }(56 \%) \text {, } \\
\text { African American } \\
(24 \%) \text {, Caucasian } \\
(16 \%), \text { Asian }(4 \%)\end{array}$ & $\begin{array}{l}\text { Colonizing }(n=0) \\
\text { Invasivet }(n=100)\end{array}$ \\
\hline $\begin{array}{l}\text { 4a. Random sample of college } \\
\text { aged women from the UM } \\
\text { community [2I] }\end{array}$ & $\begin{array}{c}\text { urine, anal orifice, } \\
\text { vaginal }\end{array}$ & Sept. to Nov. 1998 & $17-49$ & $\begin{array}{c}\text { Caucasian (65\%), } \\
\text { Asian (16\%), African } \\
\text { American (10\%), } \\
\text { Hispanic (5\%), Other } \\
\text { (5\%) }\end{array}$ & $\begin{array}{l}\text { Colonizing }(n=29) \text {, } \\
\text { Invasivet }(n=1)\end{array}$ \\
\hline $\begin{array}{l}\text { 4b. Random sample of college } \\
\text { aged men from the UM } \\
\text { community [2I] }\end{array}$ & urine, anal orifice & Sept. to Nov. 1998 & $19-45$ & $\begin{array}{c}\text { Caucasian (60\%), } \\
\text { Asian (28\%), African } \\
\text { American (4\%), } \\
\text { Hispanic (3\%), Other } \\
\text { (4\%) }\end{array}$ & $\begin{array}{l}\text { Colonizing }(n=23) \text {, } \\
\text { Invasivet }(n=1)\end{array}$ \\
\hline $\begin{array}{l}\text { 5. Pregnant women presenting at } \\
\text { the UM Medical Center for } \\
\text { prenatal care [34]. }\end{array}$ & $\begin{array}{l}\text { urine, rectal, vaginal, } \\
\text { placental }\end{array}$ & $\begin{array}{c}\text { Aug. } 1999 \text { to Mar. } \\
2000\end{array}$ & $16-42$ & $\begin{array}{l}\text { Caucasian }(67 \%), \\
\text { African American } \\
\text { (18\%), Other (7\%), } \\
\text { Unknown }(9 \%)\end{array}$ & $\begin{array}{l}\text { Colonizing }(n=49) \\
\text { Invasive† }(n=53) \\
\text { Unknown }(n=29)\end{array}$ \\
\hline
\end{tabular}

\footnotetext{
* Seventeen individuals ( 7 from collection Ia, 4 from collection $2 a, 3$ from collection $2 b$, and 3 from collection $4 b$ ) were colonized with two genetically distinct strains, as determined by pulsed-field gel electrophoresis.

†Invasive isolates originated from the blood or cerebrospinal fluid of newborns $<7$ days of age, the urine of adults at $\geq 100,000 \mathrm{cfu} / \mathrm{ml}$, pregnant women presenting for prenatal care associated with GBS isolation from the urine, and the placenta following delivery. Colonizing GBS were from the anal orifice, lower vagina, cervix or urine of healthy individuals, and sexually active college women with a urinary tract infection not caused by GBS.
}

onizing capsular serotype III strains, however, were more likely to have both rib $(\mathrm{p}=.09)$ and bac $(\mathrm{p}=.06)$, and less likely to have bca $(\mathrm{p}=.09)$.
Because a previous study also indicated that rib occurs more frequently in invasive isolates [7], we further examined its frequency by colonization site. Among invasive

Table 2: PCR primers used to amplify DNA regions specific to the genes encoding the alpha (bca) and beta (bac) $C$ proteins, and the protein Rib (rib).*

\begin{tabular}{|c|c|c|c|c|c|}
\hline Gene & Forward primer Reverse primer & Reference & Size & Annealing temperature & Extension time \\
\hline \multirow[t]{2}{*}{$b c a$} & 5'-TAACAGTTATGATACTTCACAGAC-3' & {$[\mathrm{II}]$} & $535 \mathrm{bp}$ & $68^{\circ} \mathrm{C}$ & $33 \mathrm{sec}$ \\
\hline & 5-'ACGACTTTCTTCCGTCCACTTAGG-3' & & & & \\
\hline \multirow[t]{2}{*}{ bac } & 5'-CTATTTTTGATATTGACAATGCAA-3' & {$[12]$} & 592 bp & $60^{\circ} \mathrm{C}$ & $36 \mathrm{sec}$ \\
\hline & 5'-GTCGTTACTTCCTTGAGATGTAAC-3' & & & & \\
\hline \multirow[t]{2}{*}{ rib } & 5'-CAGGAAGTGCTGTTACGTTAAAC-3' & [9] & $369 \mathrm{bp}$ & $58^{\circ} \mathrm{C}$ & $22 \mathrm{sec}$ \\
\hline & 5'-CGTCCCATTTAGGGTCTTCC-3' & & & & \\
\hline
\end{tabular}

* PCR conditions for each reaction included a five minute denaturation step at $95^{\circ} \mathrm{C}$, and 30 cycles of the following: 35 second denaturation, 40 second annealing and varying extension times. The extension temperature was $73^{\circ} \mathrm{C}$ for all reactions. 


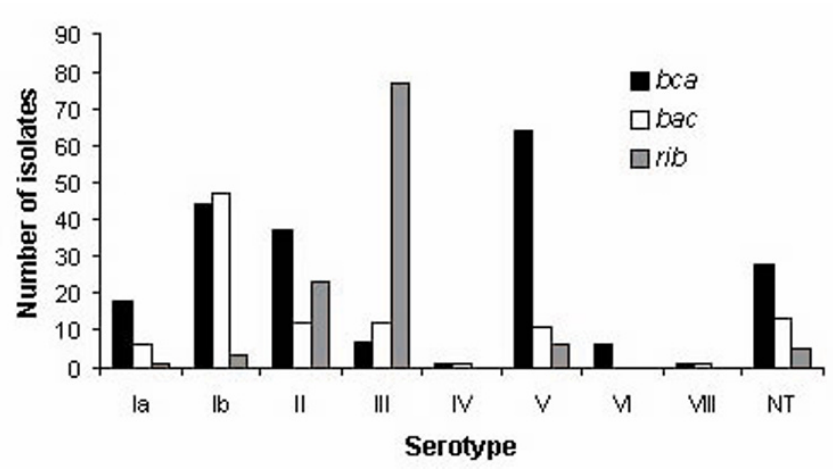

\section{Figure I}

The number of strains with genes encoding the alpha $(b c a)$ and beta (bac) $\mathrm{C}$ proteins and the protein Rib (rib) by serotypes la $(\mathrm{n}=115), \mathrm{lb}(\mathrm{n}=60)$, II $(\mathrm{n}=67)$, III $\left(\mathrm{n}=84^{*}\right)$, IV $(\mathrm{n}=$ $2), V\left(n=105^{*}\right), \mathrm{VI}\left(\mathrm{n}=7^{*}\right)$, VIII $(\mathrm{n}=1)$, and nontypeable (NT) $(n=53)$. The sample represents the maximum number of isolates tested, which varied slightly by gene; serotyping data was not available for 35 strains.

isolates from newborns, the odds of isolation from the cerebrospinal fluid (CSF) compared to blood was 3.6 higher when $r i b$ [95\% CI: $(0.86,15.44), \mathrm{p}=.04]$, and 4.1 times higher when bac [95\% CI: $(0.92,17.91), \mathrm{p}=.03]$ were present. There was no association with $b c a$. Because rib occurred in $92 \%$ of capsular serotype III isolates and was found infrequently in other serotypes, and type III occurred more frequently among infants with invasive disease, it is likely that the association with CSF is attributable to confounding. When we examined the colonization site by serotype among rib positive strains, $26 \%$ of serotype III and no serotype II strains (the only other sero- type with rib) were isolated from the CSF. By contrast, among isolates without $r i b, 6 \%, 10 \%$ and $17 \%$ of serotype Ia, II and Ib strains, respectively, were isolated from the CSF. In a similar analysis of among bac positive strains, $50 \%$ of serotype III and $18 \%$ of serotype Ib, but no serotype II or V strains were isolated from the CSF. When the analysis was restricted to serotype III strains, $r i b$ was not associated with CSF isolation, but bac was (OR: 4.7, 95\% CI: $0.43,60.74)$, although the sample size was too small to achieve statistical significance $(\mathrm{p}=.12)$.

The $b c a$ and bac genes frequently occurred together; 74 strains contained both genes among 324 strains with at least one gene ( $\mathrm{p}<.0001)$. rib was significantly less likely to occur with either bca $(11 / 333, \mathrm{p}<.0001)$ or bac $(14 /$ $224, \mathrm{p}=.01)$. These relationships were similar when stratified by isolate type with a few exceptions. Among the 14 strains with $r i b$ and $b a c, 8(57 \%)$ were invasive $(\mathrm{p}=.002)$; 7 of these 8 were from newborns and 6 of the 7 newborn strains were serotype III. Strains with both $b c a$ and rib together were more frequent in colonizing versus invasive strains $(\mathrm{p}=.03)$ as were strains with both $b c a$ and $b a c(\mathrm{p}=$ $.10)$.

\section{Discussion}

Based on the suggestion that the alpha and beta $\mathrm{C}$ proteins and protein Rib protein serve as potential vaccine GBS candidates either in glycoconjugates or alone [6-8], it was estimated in 1988, before the emergence of serotype $\mathrm{V}$ GBS, that a vaccine containing the alpha $\mathrm{C}$ protein and a serotype III component would prevent at least $90 \%$ of GBS cases [30]. Although we did not find these three genes significantly more frequently in invasive versus colonizing GBS strains, bac was found more frequently among isolates from CSF than blood in invasive serotype

Table 3: The frequency of genes encoding the alpha (bca) and beta (bac) C protein, and the protein Rib (rib) among various GBS populations.

\begin{tabular}{|c|c|c|c|c|c|c|c|c|c|}
\hline \multirow[b]{2}{*}{ GBS Collection } & \multicolumn{3}{|c|}{ alpha antigen $(b c a) \ddagger$} & \multicolumn{3}{|c|}{ beta antigen (bac) $\ddagger$} & \multicolumn{3}{|c|}{ Rib protein (rib) } \\
\hline & $\begin{array}{l}\text { Number } \\
\text { screened }\end{array}$ & $\mathrm{n}$ & $(\%)$ & $\begin{array}{l}\text { Number } \\
\text { screened }\end{array}$ & $\mathrm{n}$ & $(\%)$ & $\begin{array}{l}\text { Number } \\
\text { screened }\end{array}$ & $\mathrm{n}$ & (\%) \\
\hline $\begin{array}{l}\text { I. Sexually active college women with UTI and } \\
\text { sex partnert }\end{array}$ & 145 & 63 & $(43)$ & 147 & 26 & $(18)$ & 146 & 33 & (23) \\
\hline $\begin{array}{l}\text { 2. Sexually active college women without UTI } \\
\text { and their sex partner }\end{array}$ & 93 & 58 & $(62)$ & 93 & 26 & (28) & 93 & 17 & $(18)$ \\
\hline 3. Infected newborns $<7$ days of age & 100 & 29 & $(29)$ & 100 & 20 & $(20)$ & 100 & 28 & (28) \\
\hline 4. Random sample of college students $\dagger$ & 53 & 25 & (47) & 53 & 18 & (34) & 53 & 13 & $(25)$ \\
\hline 5. Pregnant women & 135 & 41 & (30) & $|3|$ & 18 & (14) & 134 & 27 & (20) \\
\hline Total & 526 & 216 & $(4 I)$ & 524 & 108 & $(21)$ & 526 & 118 & $(22)$ \\
\hline
\end{tabular}

Note: $\mathrm{n}(\%)$ represents the number of participants with the respective gene in each population; the number screened varies slightly by gene and population because a result could not be obtained for 4 strains tested for rib and bca, and 6 strains tested for bac despite repeated testing. †There was no difference in gene frequency by gender so the results were combined for presentation.

¥Using the Chi-square test, a significant difference at the $p=.05$ significance level was observed between bca frequencies in collection 2 versus 3 ( $p$ $<.000 \mathrm{I}), 5(\mathrm{p}<.000 \mathrm{I})$ and I $(\mathrm{p}=.004)$; and between bac frequencies in collection 2 versus $5(\mathrm{p}=.008)$. 
Table 4: Frequency of genes encoding the alpha (bca) and beta (bac) C proteins, and the protein Rib (rib) among invasive versus colonizing group B streptococcal isolates by serotype.

\begin{tabular}{|c|c|c|c|c|c|c|}
\hline & \multicolumn{3}{|c|}{ Invasive n (\%) } & \multicolumn{3}{|c|}{ Colonizing n (\%) } \\
\hline & bca & bac & rib & bca & bac & rib \\
\hline Overall freq. & $29 / 100(29)$ & $20 / 100(20)$ & $28 / 100(28)$ & $167 / 360(46)^{*}$ & $82 / 360(23)$ & $72 / 360(20) \dagger$ \\
\hline \multicolumn{7}{|l|}{ By Serotype } \\
\hline la & $0 / 33(0)$ & $0 / 43(0)$ & $0 / 33(0)$ & $|8 / 7|(25)^{*}$ & 6/7I (8)† & I/7I (I) \\
\hline lb & $12 / 12(100)$ & $11 / 12(92)$ & $0 / 12(0)$ & $29 / 42(69)^{*}$ & $32 / 42(76)$ & $3 / 42(7)$ \\
\hline II & $8 / 15(53)$ & $2 / 15(13)$ & $5 / 15(33)$ & $25 / 45(56)$ & $10 / 45(22)$ & $15 / 45(33)$ \\
\hline III & $0 / 23(0)$ & $6 / 23(26)$ & $23 / 23(100)$ & 5/44 (II)† & 4/44 (9)† & $39 / 44(89) \dagger$ \\
\hline IV & $0 / 0(0)$ & $0 / 0(0)$ & $0 / 0(0)$ & $\mathrm{I} / 2(50)$ & $\mathrm{I} / 2(50)$ & $0 / 2(0)$ \\
\hline $\mathbf{v}$ & $8 / 15(53)$ & $1 / 15(7)$ & $0 / 15(0)$ & $51 / 76(67)$ & $10 / 78(13)$ & 6/78 (8) \\
\hline VI & $0 / 0(0)$ & $0 / I(0)$ & $0 / 0(0)$ & $5 / 6(83)$ & $0 / 6(0)$ & $0 / 0(0)$ \\
\hline VIII & $0 / 0(0)$ & $0 / 0(0)$ & $0 / 0(0)$ & $\mathrm{I} / \mathrm{I}(100)$ & $\mathrm{I} / \mathrm{I}(100)$ & $0 / 0(0)$ \\
\hline NT & $0 / 0(0)$ & $0 / 10(0)$ & $0 / 0(0)$ & $23 / 4 I(56)$ & |3/4| (32) & $5 / 4 I(12)$ \\
\hline
\end{tabular}

Note: Serotype data are missing for 30 strains.

*The difference in the gene frequency between invasive and colonizing populations is statistically significant at $p<.05$ using the Chi square test. †Marginally significant Chi square estimate $(.06<p<.10)$

III isolates from newborns, suggesting it may increase disease severity.

Although we detected differences in the frequency of specific genes, it is possible that the encoded proteins are differentially expressed [31,32] and thus, differences in pathogenicity could be attributable to differences in gene expression. A prior study demonstrated that protein Rib [7] was present in more invasive versus colonizing serotype III strains. In this study, invasive strains were more likely to have rib $(\mathrm{p}=.09)$, but the association was only marginally significant. A similar observation was found for $b a c(\mathrm{p}=.06)$, which is consistent with a prior report [18]. However, we cannot exclude the possibility that the differences in collection date and geographic location are responsible for this result. Further, and possibly more important, the isolates assessed may contain other unknown virulence characteristics important to invasion, as the virulence of GBS is probably attributable to multiple genes. Our collections of invasive isolates were limited to those from newborns, pregnant women and healthy young women. It is possible that these virulence genes might have different impacts in other susceptible populations, such as the elderly or those with underlying chronic disease.

\section{Conclusion}

We observed only a marginally significant difference in $b a c, b c a$ and $r i b$ frequency between invasive and colonizing serotype III strains, thereby raising the possibility that other genes explain the association of serotype III with invasive disease. It is noteworthy, however, that both rib and $b a c$ were found more frequently in the newborn serotype III isolates, while $b c a$ was found less frequently. Because various genotyping methods, such as multilocus sequence typing (MLST), have distinguished between colonizing and invasive strains, [33] this warrants further study. Using the framework provided by MLST, for example, may allow us to assess the distribution of these genes by sequence types found to be associated with invasiveness. In addition, it is clear that GBS disease pathogenesis is complex, thus novel virulence genes need to be identified and evaluated to understand their role in the pathogenic process, and provide additional vaccine targets. Recently published GBS DNA sequences [34-36] will facilitate the identification of these novel factors.

\section{Competing interests}

The author(s) declare that they have no competing interests.

\section{Authors' contributions}

SDM conducted the data analysis and drafted the manuscript, MK performed the PCR on strains yielding an equivocal result; CFM and BF oversaw and participated in the study design, analysis and writing; $\mathrm{KJK}$ and SMB performed the dot blot assays; and CJB provided strains, performed serotyping and assisted with the manuscript. All authors read and approved the final manuscript.

\section{Acknowledgements}

We thank Patricia Tallman for maintaining the GBS collections; Melissa E. Ward for serotyping the GBS isolates; Lixin Zhang for technical advice; Gunnar Lindahl for providing strain BMI I0; and Yuan Gu for performing dot blot hybridization. This work was supported by Public Health Service grant Al44868 (BF) and AI5 I 675 (BF) from the National Institute of Health (NIH), and in part by NIH Public Health Service grant AI06608I (SDM). Collection, maintenance of isolates and serotyping by $\mathrm{CJB}$ was supported in part by NIH-NIAID contract NOI AI75326. Serotyping was paid in part by grant 334-SAP/99 (SDM) from the Blue Cross Blue Shield of Michigan Foun- 
dation, and the University of Michigan Medical School's Advisory Council on Clinical Research (Mark D. Pearlman, M.D.)

\section{References}

I. Schrag SJ, Zell ER, Lynfield R, Roome A, Arnold KE, Craig AS, Harrison LH, Reingold A, Stefonek K, Smith G, Gamble M, Schuchat A: A population-based comparison of strategies to prevent earlyonset group B streptococcal disease in neonates. N Engl J Med 2002, 347:233-239.

2. Harrison LH, Elliott JA, Dwyer DM, Libonati JP, Ferrieri P, Billmann L, Schuchat A: Serotype distribution of invasive group B streptococcal isolates in Maryland: implications for vaccine formula tion. Maryland Emerging Infections Program. J Infect Dis 1998 , 177:998-1002.

3. Davies HD, Raj S, Adair C, Robinson J, McGeer A: Populationbased active surveillance for neonatal group B streptococca infections in Alberta, Canada: implications for vaccine for mulation. Pediatr Infect Dis J 200 I, 20:879-884.

4. Baker CJ, Edwards MS: Group B streptococcal conjugate vaccines. Arch Dis Child 2003, 88:375-378.

5. Manning SD: Molecular epidemiology of Streptococcus agalactiae (group B Streptococcus). Front Biosci 2003, 8:s I- I8.

6. Baker C): Immunization to prevent group B streptococcal disease: victories and vexations. J Infect Dis 1990, I6 I:917-921.

7. Stalhammar-Carlemalm M, Stenberg L, Lindahl G: Protein rib: a novel group B streptococcal cell surface protein that confers protective immunity and is expressed by most strains causing invasive infections. I Exp Med 1993, 177:1593-1603.

8. Gravekamp C, Kasper DL, Paoletti LC, Madoff LC: Alpha C protein as a carrier for type III capsular polysaccharide and as a protective protein in group B streptococcal vaccines. Infect Immun 1999, 67:2491-2496.

9. Wastfelt M, Stalhammar-Carlemalm M, Delisse AM, Cabezon T, Lindahl G: Identification of a family of streptococcal surface proteins with extremely repetitive structure. J Biol Chem 1996 , 27|: | 8892- | 8897

10. Bevanger L, Maeland JA: Complete and incomplete Ibc protein fraction in group B streptococci. Acta Pathol Microbiol Scand [B] | 979, 87B:51-54.

II. Michel JL, Madoff LC, Olson K, Kling DE, Kasper DL, Ausubel FM: Large, identical, tandem repeating units in the $C$ protein alpha antigen gene, bca, of group B streptococci. Proc Nat Acad Sci U S A 1992, 89:10060-10064.

12. Jerlstrom PG, Chhatwal GS, Timmis KN: The IgA-binding beta antigen of the $C$ protein complex of Group B streptococci: sequence determination of its gene and detection of two binding regions. Mol Microbiol I991, 5:843-849.

13. Lachenauer CS, Baker CJ, Baron MJ, Kasper DL, Gravekamp C, Madoff LC: Quantitative determination of immunoglobulin $\mathbf{G}$ specific for group $B$ streptococcal beta $\mathbf{C}$ protein in human maternal serum. J Infect Dis 2002, I 85:368-374.

14. Johnson DR, Ferrieri P: Group B streptococcal lbc protein antigen: distribution of two determinants in wild-type strains of common serotypes. J Clin Microbiol 1984, 19:506-510.

15. Madoff LC, Hori S, Michel JL, Baker CJ, Kasper DL: Phenotypic diversity in the alpha $\mathbf{C}$ protein of group $\mathbf{B}$ streptococci. Infect Immun 1991, 59:2638-2644.

16. Hickman ME, Rench MA, Ferrieri P, Baker Cl: Changing epidemiology of group B streptococcal colonization. Pediatrics 1999 104:203-209.

17. Maeland JA, Brakstad OG, Bevanger L, Kvam Al: Streptococcus agalactiae beta gene and gene product variations. J Med Microbiol 1997, 46:999-1005.

18. Berner R, Bender A, Rensing C, Forster J, Brandis M: Low prevalence of the immunoglobulin-A-binding beta antigen of the $C$ protein among Streptococcus agalactiae isolates causing neonatal sepsis. Eur J Clin Microbiol Infect Dis 1999, I 8:545-550.

19. Dore N, Bennett D, Kaliszer M, Cafferkey M, Smyth C): Molecular epidemiology of group B streptococci in Ireland: associations between serotype, invasive status and presence of genes encoding putative virulence factors. Epidemiol Infect 2003, | $31: 823-833$

20. Manning SD, Tallman P, Baker CJ, Gillespie B, Marrs CF, Foxman B: Determinants of co-colonization with group $B$ streptococcus among heterosexual college couples. Epidemiology 2002 , 13:533-539.

21. Bliss SJ, Manning SD, Tallman P, Baker CJ, Pearlman MD, Marrs CF, Foxman B: Group B Streptococcus colonization in male and nonpregnant female university students: a cross-sectional prevalence study. Clin Infect Dis 2002, 34: I84-190.

22. Manning SD, Foxman B, Pierson CL, Tallman P, Baker CJ, Pearlman MD: Correlates of antibiotic-resistant group $B$ streptococcus isolated from pregnant women. Obstet Gynecol 2003, I 0 I :74-79.

23. Zaleznik DF, Rench MA, Hillier S, Krohn MA, Platt R, Lee ML, Flores $A E$, Ferrieri $P$, Baker CJ: Invasive disease due to group B Streptococcus in pregnant women and neonates from diverse population groups. Clin Infect Dis 2000, 30:276-28I.

24. Manning SD, Pearlman MD, Tallman P, Pierson CL, Foxman B: Frequency of antibiotic resistance among group B Streptococcus isolated from healthy college students. Clin Infect Dis 200I, 33:EI37-9.

25. Li J, Kasper DL, Ausubel FM, Rosner B, Michel JL: Inactivation of the alpha $C$ protein antigen gene, bca, by a novel shuttle/suicide vector results in attenuation of virulence and immunity in group B Streptococcus. Proc Natl Acad Sci U S A 1997, 94: I325I-13256.

26. Zhang L, Gillespie B, Marrs CF, Foxman B: Optimization of a fluorescent-based phosphor imaging dot blot DNA hybridization assay to assess Escherichia coli virulence gene profiles. Microbiol Methods 200I, 44:225-233.

27. Foxman B, Zhang L, Tallman P, Palin K, Rode CK, Bloch CA, Gillespie $B$, Marrs CF: Virulence characteristics of Escherichia coli causing first urinary tract infection predict risk of second infection. J Infect Dis 1994, I 72: I536-154I.

28. Borchardt SM, Foxman B, Chaffin DO, Rubens CE, Tallman PA, Manning SD, Baker CJ, Marrs CF: Comparison of DNA dot blot hybridization and lancefield capillary precipitin methods for group B streptococcal capsular typing. J Clin Microbiol 2004, 42: $146-150$

29. SAS Institute Inc.: The SAS System for Windows. 8e edition. Cary, NC, ; 1999.

30. Insel RA: Maternal immunization to prevent neonatal infections. N Engl ] Med 1988, 3 19:1219-1220.

31. Suvorov A, Dmitriev A, Ustinovitch I, Schalen C, Totolian AA Molecular analysis of clinical group B streptococcal strains by use of alpha and beta gene probes. FEMS Immunol Med Microbiol 1997, I 7: 149-154.

32. Maeland JA, Brakstad OG, Bevanger L, Krokstad S: Distribution and expression of bca, the gene encoding the $c$ alpha protein, by Streptococcus agalactiae. J Med Microbiol 2000, 49:193-198.

33. Jones N, Bohnsack JF, Takahashi S, Oliver KA, Chan MS, Kunst F, Glaser P, Rusniok C, Crook DW, Harding RM, Bisharat N, Spratt BG: Multilocus sequence typing system for group $B$ streptococcus. J Clin Microbiol 2003, 41:2530-2536.

34. Glaser P, Rusniok C, Buchrieser C, Chevalier F, Frangeul L, Msadek T, Zouine M, Couve E, Lalioui L, Poyart C, Trieu-Cuot P, Kunst F: Genome sequence of Streptococcus agalactiae, a pathogen causing invasive neonatal disease. Mol Microbiol 2002 , 45: $1499-1513$.

35. Tettelin H, Masignani V, Cieslewicz MJ, Eisen JA, Peterson S, Wessels MR, Paulsen IT, Nelson KE, Margarit I, Read TD, Madoff LC, Wolf AM, Beanan MJ, Brinkac LM, Daugherty SC, DeBoy RT, Durkin AS, Kolonay JF, Madupu R, Lewis MR, Radune D, Fedorova NB, Scanlan D, Khouri H, Mulligan S, Carty HA, Cline RT, Van Aken SE, Gill J, Scarselli M, Mora M, lacobini ET, Brettoni C, Galli G, Mariani M, Vegni F, Maione D, Rinaudo D, Rappuoli R, Telford JL, Kasper DL, Grandi G, Fraser CM: Complete genome sequence and comparative genomic analysis of an emerging human pathogen, serotype V Streptococcus agalactiae. Proc Natl Acad Sci U S A 2002, 99: $12391-12396$.

36. Tettelin H, Masignani V, Cieslewicz MJ, Donati C, Medini D, Ward NL, Angiuoli SV, Crabtree J, Jones AL, Durkin AS, Deboy RT, Davidsen TM, Mora M, Scarselli M, Margarit y Ros I, Peterson JD, Hauser CR, Sundaram JP, Nelson WC, Madupu R, Brinkac LM, Dodson RJ, Rosovitz MJ, Sullivan SA, Daugherty SC, Haft DH, Selengut J, Gwinn ML, Zhou L, Zafar N, Khouri H, Radune D, Dimitrov G, Watkins K, O'Connor KJ, Smith S, Utterback TR, White O, Rubens CE, Grandi G, Madoff LC, Kasper DL, Telford JL, Wessels MR, Rappuoli R, Fraser $\mathrm{CM}$ : Genome analysis of multiple pathogenic isolates of 
Streptococcus agalactiae: implications for the microbial "pan-genome". Proc Natl Acad Sci U S A 2005, 102:13950-13955.

\section{Pre-publication history}

The pre-publication history for this paper can be accessed here:

http://www.biomedcentral.com/1471-2334/6/116/pre pub

Publish with Bio Med Central and every scientist can read your work free of charge

"BioMed Central will be the most significant development for disseminating the results of biomedical research in our lifetime. " Sir Paul Nurse, Cancer Research UK

Your research papers will be:

- available free of charge to the entire biomedical community

- peer reviewed and published immediately upon acceptance

- cited in PubMed and archived on PubMed Central

- yours - you keep the copyright 